\title{
Gymnodinioid Dinoflagellates (Gymnodiniales, Dinophyceae) in the Open Pacific Ocean
}

\author{
Fernando Gómez* \\ Laboratoire d'Océanographie et de Biogéochimie, Centre d'Océanologie de Marseille, UMR 6535, \\ CNRS-Université de la Méditerranée, 163 Avenue de Luminy, \\ Case 901, F-13288 Marseille, France
}

\begin{abstract}
Records of selected gymnodinioid dinoflagellates from the open waters in the vicinity of the Kuroshio and Oyashio Currents, the Philippine, Celebes, Sulu and South China Seas, western and central equatorial and southeast Pacific Ocean are described and illustrated. The species Gymnodinium fusus Schütt, Gyrodinium falcatum Kofoid et Swezy, G. caudatum Kofoid et Swezy, G. sugashimanii J. Cachon et al. and Pseliodinium vaubanii Sournia are considered to be morphotypes of a single species, that until further studies can establish the correct genus, are named G. falcatum. This study is the first to record individuals of G. falcatum with very long curly extensions. Other gymnodinioid dinoflagellates that showed bifurcated hyposomes may be related to Gyrodinium bifurcatum Kofoid et Swezy or cells of thecate dinoflagellates exuviated from their thecae. Some specimens showed a rigid cover, although no discernible thecal plates. In this group, the most common species was Ptychodiscus noctiluca Stein and, for the first time, a micrograph of a tentative specimen of the genus Berghiella Kofoid et Michener is reported. The validity of the genera Berghiella and Balechina Loeblich Jr. et Loeblich III with thick cell covers is discussed. Several species with apical extensions, other unknown taxa with distinctive shapes, and colonial forms are illustrated. The diversity of gymnodinioid dinoflagellates is underinvestigated in the open ocean.
\end{abstract}

Key Words: Balechina, Berghiella, Gymnodinium, Gyrodinium, Pacific Ocean, Pseliodinium, Ptychodiscus, unarmoured dinoflagellates

\section{INTRODUCTION}

Two major groups of dinoflagellates may be distinguished: thecate or armoured species with discernible thecal plates, and athecate, unarmoured or 'naked' species without plates or with plates that are barely visible under a light microscope. Although from a phylogenetical point of view there is no clear-cut distinction between armoured and unarmoured species, there is a high difference in the knowledge of both groups in the open ocean. The dinoflagellates with discernible thecal plates tend to be more robust, the morphology less affected by net sampling and the tabulation, i.e. disposition and shape of the thecal plates, can be used for the species diagnosis. On the other hand, the unarmoured dinoflagellates of the order Gymnodiniales Lemmermann tend to be delicate, easily damaged by net sampling, and the specimens may be too distorted by fix-

*Corresponding author (fernando.gomez@fitoplancton.com) ation to be identified. The live specimens can be easily deformed when they are examined under the microscope, being difficult distinguish even at the genus level.

Most of the studies of gymnodinioid dinoflagellates are focused on the species responsible of harmful algal blooms, easily accessible in high numbers in coastal waters. Numerous autotrophic species are cultivable and the abundant material available allows sophisticated morphological and molecular studies. However, in the open ocean the abundance of unarmoured dinoflagellates is low. Numerous species are heterotrophic and the cultures are unable to reproduce the low turbulence, oligotrophy and low cell abundance that predominate in the open ocean. Morphological characters such as the body extensions of the oceanic species are inhibited in cultures and the fast-growing morphotypes of each species are selected. For example neritic morphotypes such as Karenia papilionacea Haywood et Steidinger were first described in the open ocean as the genera with body extensions Brachidinium F.J.R. Taylor, Asterodinium Sournia and Microceratium Sournia (Gómez et al. 2005; 
Gómez 2006).

The low abundance and the limited ship-time, hinder on-board observations of the live specimens of oceanic unarmoured dinoflagellates. The net sampling facilitates the collection, but the smaller and fragile specimens may be inefficiently retained, the body extensions damaged, and their diversity subsequently underestimated in comparison with larger or resistant taxa. The main problem when identifying the gymnodinioid dinoflagellates is an almost immediate disappearance of structures such as the apical groove currently used for the species diagnosis. The fixation causes cell deformation and the live specimens viewed with a microscope are subjected to incessant movements and they disintegrate when they cease to move. The cell shape and body extensions change under the stress due to specimen capture, transport and manipulation at the laboratory. All these factors are responsible for the bias in the knowledge towards the thecate dinoflagellates, whereas the unarmoured dinoflagellates are likely one of the least known groups of the open ocean phytoplankton.

In the present study, gymnodinioid dinoflagellates were collected from several contrasting regions of the open Pacific using the same methodology. Seawater samples were collected using Niskin bottles in order to reduce the probability of damage of the delicate unarmoured dinoflagellates or the under-representation of the smaller forms compared with net sampling. The specimens were immediately fixed with Lugol's solution with the aim to preserve as much as possible the usual morphology under natural conditions. In the laboratory, the seawater samples were concentrated by sedimentation, assumed as the softer concentration method. This methodology has allowed the observation, for the first time, of several genera of gymnodiniaceans, previously placed in the order Brachidiniales Loeblich III ex Sournia (Gómez et al. 2005; Gómez 2006), as well as new or unknown gymnodinioid taxa in the Pacific Ocean (Gómez 2007a, b). The present study compiles the most interesting gymnodinioid dinoflagellates, with particular emphasis on the taxa with body extensions, found in the open Pacific Ocean.

\section{MATERIALS AND METHODS}

Samples were collected during 12 cruises in the Pacific Ocean. Sample collection and light microscopical methods used were described in Gómez (2006, 2007a, b) (Fig. 1 ). Water samples at each station were collected using

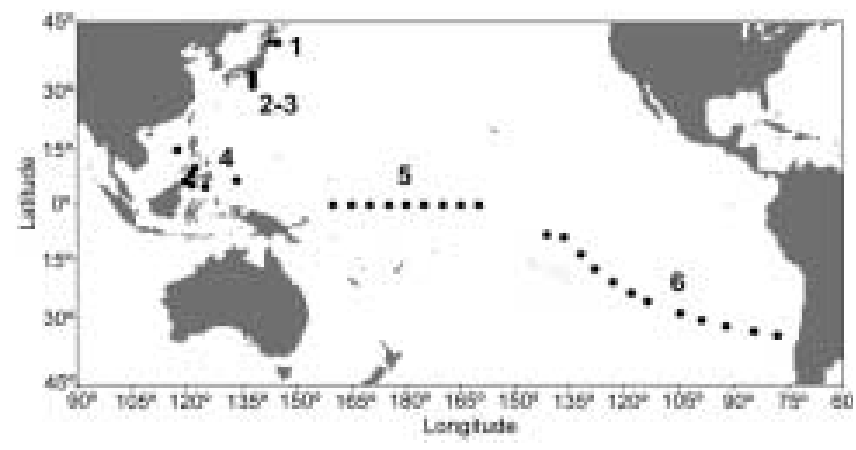

Fig. 1. Sampling stations in the Pacific Ocean (solid circles). 1. Oyashio Current. 2, 3. Kuroshio Current and Philippine Sea in May and July, respectively. 4. Celebes, Sulu and South China seas. 5. Western and central equatorial Pacific. 6. Southeast Pacific Ocean.

Niskin bottles in the range $0-280 \mathrm{~m}$ depth, were preserved with acidified Lugol's solution and stored at $5^{\circ} \mathrm{C}$. Samples of $500 \mathrm{~mL}$ were concentrated by sedimentation in glass cylinders. During a six-day settling period, the top $450 \mathrm{~mL}$ of the sample was progressively and slowly siphoned off with small-bore tubing. $50 \mathrm{~mL}$ of the concentrate representing $500 \mathrm{~mL}$ whole water sample was settled in composite settling chambers. The entire chamber was scanned at $200 \times$ magnification under a Nikon (Tokyo, Japan) or Olympus (Tokyo, Japan) inverted microscope equipped with a digital camera. The specimens were photographed at $600 \times$ or $1000 \times$ magnification for samples collected in the NE and Equatorial Pacific and at $400 \times$ magnification for samples collected in the South Pacific.

\section{RESULTS}

\section{Gyrodinium falcatum}

The presence of processes or body extensions facilitates the identification of gymnodinioid cells from Lugolpreserved material. Most of the records of fusiform or ovate cells with a single extension from the episome and the hyposome were considered to be Gyrodinium falcatum Kofoid et Swezy. The shorter cells were spindle-shaped (Figs 2, 7) and other cells showed longer extensions from the episome and hyposome (Figs 3-6, 8-9). The ending of the antapical extension tended to be more pointed than the apical one (Figs 2-9). In some specimens the apical extension was thicker at the tip (Figs 9, 12). Other specimens showed a long apical extension, whereas the antapical extension was scarcely developed (Figs 10-12). The length and shape of the extensions showed a high variability. The cell transdiameter was $18-35 \mu \mathrm{m}$, more 

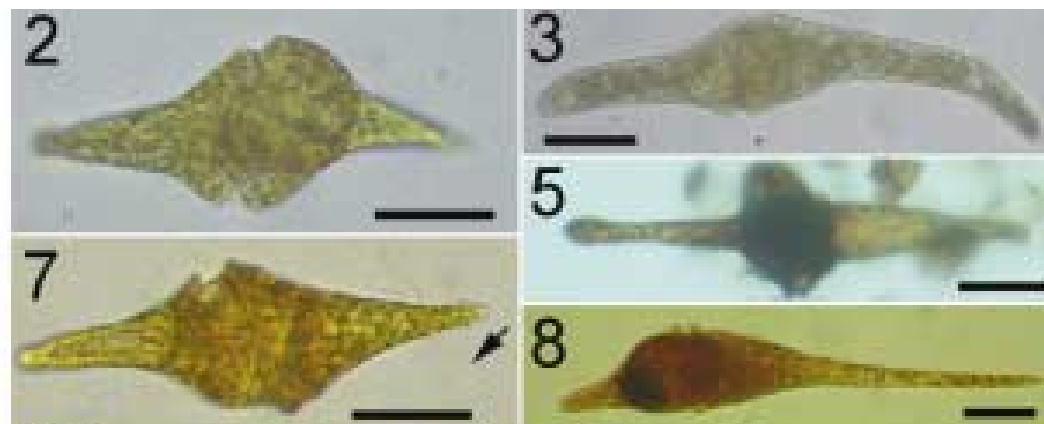

5
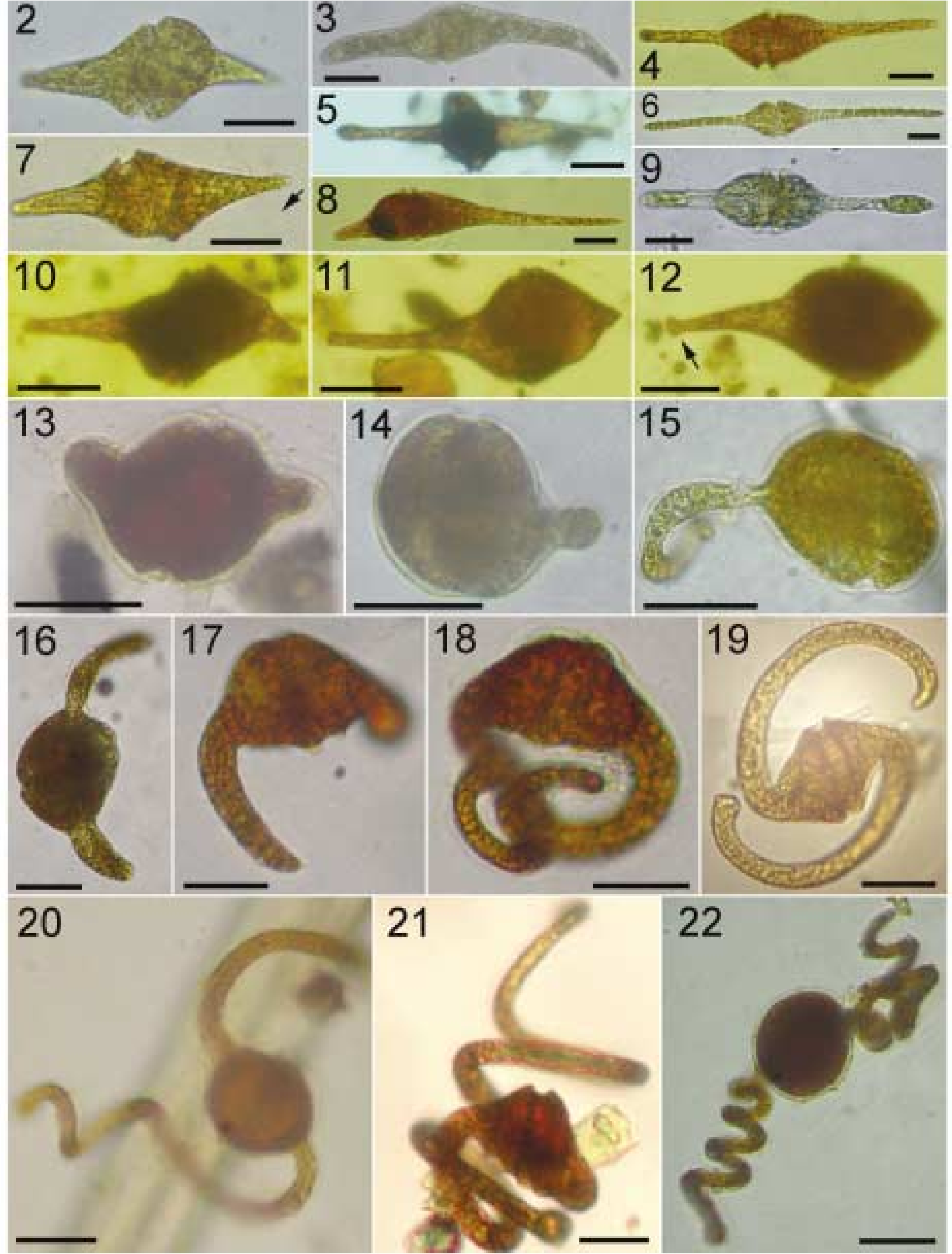

Figs 2-22. Photomicrographs of specimens ascribed to morphotypes of Gyrodinium falcatum, bright-field optics. See table 1 for the localization of the records. Figs 2, 7. Spindle-shaped specimens close to Gymnodinium fusus. The arrow indicates the longitudinal flagellum. Figs 3, 5. Specimens with thick extensions. Figs 4, 6, 8, 9. Specimens with long straight extensions. Figs 10-12. Cells with short extensions. Fig. 13. Tentatively Gyrodinium caudatum. Figs 13-15. Specimens with globular cell body and short or lacking extensions. Note the hyaline capsule that covers the cells, also in figs 18 and 22. Figs 16-19. Pseliodinium vaubanii. Figs $20-22$. Specimens with long curly extensions. Scale bars: $20 \mu \mathrm{m}$. 
usually $\sim 25 \mu \mathrm{m}$. The cingulum was descending, lefthanded and deep. The ends were displaced $1 / 4$ to $1 / 3$ of the body length. The chromatophores were small and numerous and the nucleus was centrally located. Often the specimens showed a hyaline wall, tentatively considered as a temporary cyst formed under stress (Figs 13-15, $18,22)$. Some specimens showed a rounder cell body and very narrow extensions. The morphology was closer to that described for Gyrodinium caudatum Kofoid et Swezy (Fig. 13) that is here considered as a synonym of G. falcatum. Other specimens with a rounded cell body showed a single extension (Figs 14-15). These specimens showed some resemblance to Proterythropsis crassicaudata Kofoid et Swezy or Warnowia hataii (Kofoid et Swezy) Schiller that were described as having a single extension, although they may correspond to the retraction of one of the body extensions in G. falcatum (Figs 14-15). The long apical and antapical extensions may be straight or curved. The bracelet-shaped specimens with long and curved extensions have been ascribed to Pseliodinium vaubanii Sournia that is here considered as a synonym of G. falcatum (Figs 16-19). In the present study, for the first time, are illustrated specimens with very long and curly extensions, even longer than in the original illustrations of $P$. vaubanii (Figs 20-22). It is uncertain whether this curled effect is an artifact of the fixation.

\section{Gymnodinioid cells with bilobed hyposome}

While Gyrodinium falcatum is characterized by a single body extension from the hyposome and episome, the hyposome of other gymnodinioid cells were drawn out into two extensions or it was bifurcated by the sulcus. In the figures 23-24 is shown a specimen apparently affected by swelling or shrinkage due to the fixation. The cell body was lenticular and wide at the cingulum level. The lower margin of the cingulum showed an extruded structure that encircled the cell, being tentatively considered as the lower cingular list. A straight blunted apical extension emerged from the episome and two slightly divergent rounded tips from an elongated hyposome. The cell size was $50 \mu \mathrm{m}$ in length and $30 \mu \mathrm{m}$ in width. The specimen showed a few particles attached or what may tentatively be described as epiphytes in the episome (Figs 23-24). Beyond this specimen collected in the central Equatorial Pacific, another specimen collected in the temperate South Pacific showed a similar cell shape and extensions, although it differed in the wider cell body at the cingulum level, with a less swollen appearance and a narrower hyposome. The cell size was $68 \mu \mathrm{m}$ in length and $49 \mu \mathrm{m}$ wide at the cingulum level. From the antapical view, the cell shape was bilobed and compressed at the sulcus level. It also showed numerous globular epiphytes apparently joined by a filament to the cell surface (Figs 25-26).

Another specimen did not show a bifurcated hyposome (Figs 27-28). However, it is included here due to the very wide cell body with a disc-like shape at the cingulum level. The cell size was $60 \mu \mathrm{m}$ in length and $46 \mu \mathrm{m}$ in width. The episome was conical with a rounded apex. The hyposome was elongated, concave in its middle longitudinal part and rounder at the antapex. The general appearance resembled a pacifier (Figs 27-28). Another specimen from the temperate North Pacific showed an antero-posteriorly elongated cell body, $90 \mu \mathrm{m}$ in length, with a conical episome of convex outline (Figs 29-31). The episome was culminated by a blunted apical extension. The anterior and posterior margins of the cingulum showed concentric rings that are considered to be cingular lists. The hyposome was longer than the episome and bifurcated by two slightly divergent antapical processes (Figs 29-30). Other specimens from the tropical South Pacific showed a similar morphology, slightly less elongated (70 $\mu \mathrm{m}$ long) and the antapical processes were not divergent (Fig. 31). These specimens were $65-70 \mu \mathrm{m}$ in length and $24-26 \mu \mathrm{m}$ in width. In figure 32 shows a specimen with a highly elongated cell body (108 $\mu \mathrm{m}$ long, 19 $\mu \mathrm{m}$ wide) and cingular lists as observed in two previous specimens (Fig. 32).

Another specimen showed a semicircular episome, two antapical processes with rounded-tips, and lacked any apical protuberance (Fig. 33). This specimen, especially the shape of the episome resembled Gymnodinium contractum Kofoid et Swezy or Gymnodinium arcuatum Kofoid, and is not dissimilar to morphotypes of the common Akashiwo sanguinea (Hirasaka) G. Hansen et Moestrup. Other specimens corresponded to the shape of more typical gymnodinioid cells (Figs 34-35). The hyposome was conical and the hyposome was bifurcated into two conical extensions with more or less pointed tips (Figs 34-35). The specimen shown in figure 36 showed an unarmoured dinoflagellate under division, with the nucleus of each daughter cell already separated. This is used as an example of the specimens under division (Fig. 36), and should not be mistaken for dinoflagellates with truly bifurcated hyposome.

\section{Unarmoured dinoflagellate with thick cell covers}

Several specimens showed a thick rigid cell cover, 


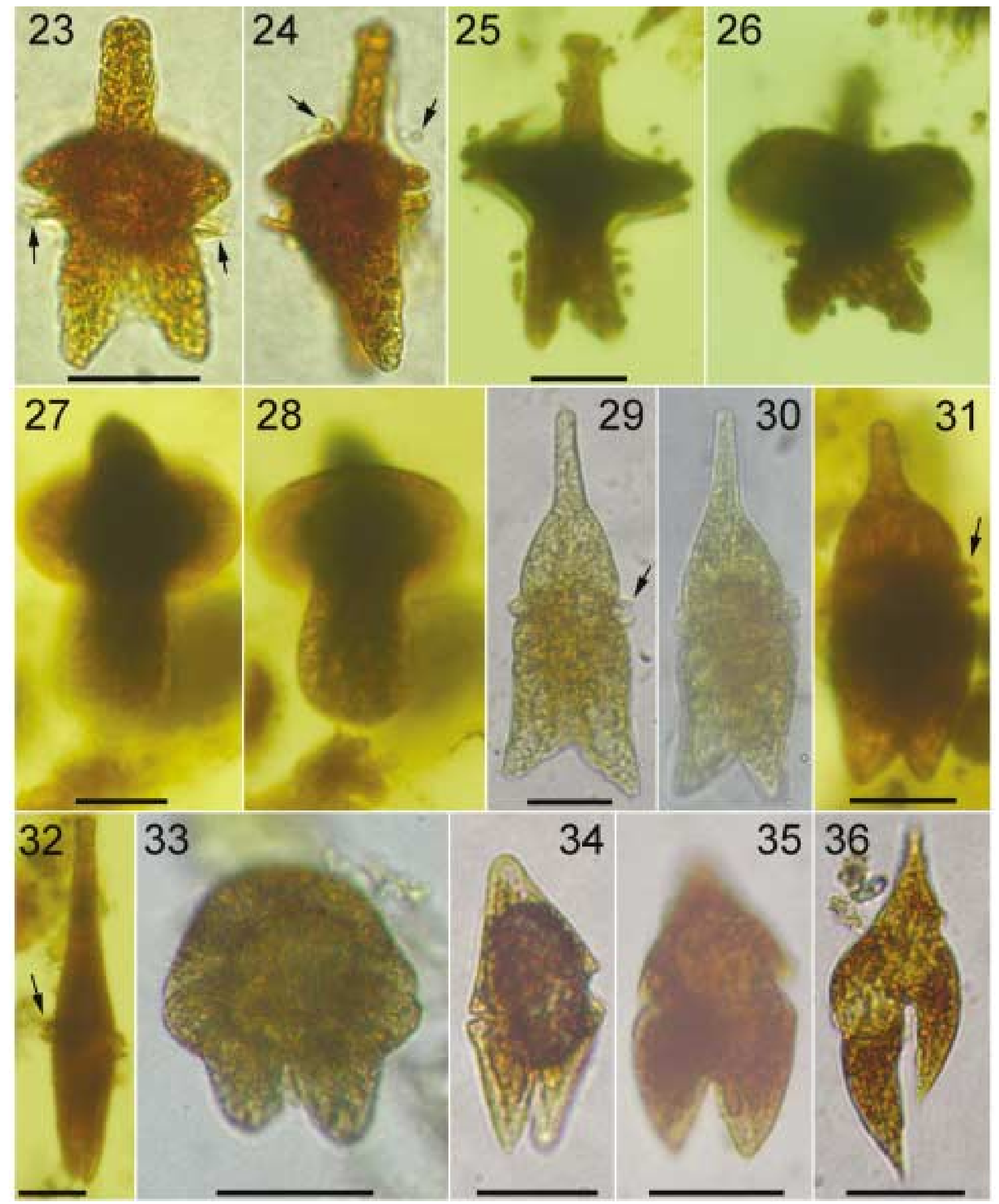

Figs 23-36. Photomicrographs of gymnodinioid individuals with bifurcated hyposome (except figs 27-28), bright-field optics. See table 1 for the localization of the records. Figs 23-24. Swollen specimen with bifurcated hyposome and an apical horn. The arrow in the figs 23 and 24 indicates the protuberant cingular list and tentative epiphytes, respectively. Figs 25-26. Disc-like cell body with bifurcated hyposome and an apical horn. Figs 27-28. Pacifier-shaped specimen. Figs 29-30. Elongated specimen with bifurcated hyposome. Fig. 31. Another specimen. Fig. 32. A very elongated specimen with cingular lists. The arrows in the figs 29,31 and 32 indicate the marked cingular lists. Fig. 33. Specimen with semicircular episome. Figs 34-35. Two specimens with biconical hyposome. Fig. 36. Gymnodinioid cell under division. Scale bars: $20 \mu \mathrm{m}$. 
although thecal plates were not discernible. Apparently the best known species with these characteristics is Ptychodiscus noctiluca Stein (Figs 37-39). The records in the NW and equatorial Pacific were restricted to a few specimens in the North Philippine Sea and the western Equatorial Pacific, whereas in the South Pacific species were more commonly found in the eutrophic regions investigated. The highest abundance $\left(18\right.$ cells $\left.\mathrm{L}^{-1}\right)$ was recorded near the Marquesas Islands Archipelago and the offshore Perú-Chile Current. The cell body was compressed apical-antapically, with swollen or flattened shapes. The episome showed a prominent keel-like carina on the ventral side and the hyposome was domed. The cingulum was horizontal, wide and deep. The sulcus started on the carina and formed a groove in the hyposome. The size was $\sim 30 \mu \mathrm{m}$ in diameter (Fig. 37).

The specimen in figure 40 showed a shape that bore some resemblance to the thecate genus Gonyaulax Diesing, with a truncate apical horn and a wide horizontal cingulum. The base of the hyposome was wide and slightly concave in its middle. The cell size was $70 \mu \mathrm{m}$ in length and $51 \mu \mathrm{m}$ in width (Fig. 40). The contour of the cell was well marked and no thecal plates were discernible. These features suggest that the specimen may tentatively belong to the poorly defined genus, Berghiella Kofoid et Michener, never reported in the Pacific Ocean since the original description and for the first time here illustrated in a photomicrograph (Fig. 40). It is difficult to confirm the identity as little is known about Berghiella due to the obscure description available, with too brief diagnosis and lack of illustrations. This specimen did not noticeably differ from other gymnodinioid dinoflagellate, being slightly smaller and with more pronounced processes (Fig. 41).

\section{Other dinoflagellates with body extensions}

The elongation of the apical extensions constitutes a morphological character that varies intraspecifically. For example, a two-cell chain, assumed to be of the same species and $30 \mu \mathrm{m}$ in width, showed one individual with a blunted apex, whereas the other individual showed an elongated episome (Fig. 42). Figures 43-44 show two specimens collected in the same sampling station, both with similar hyposome and general resemblance, and both presumably belong to the same species. One of the specimens showed a longer apical extension than the other one (Figs 43-44). These are two examples of the intraspecific variation of the extensions in other species beyond the ubiquitous Gyrodinium falcatum. Another specimen of $83 \mu \mathrm{m}$ in length showed a highly developed, straight and truncated apical extension that emerged from an eccentric position (Figs 45-46). The outline of the cell body was widest in the central part and showed a short triangular antapical extension (Figs 45-46). Several unidentified gymnodinioid cells (70-80 $\mu \mathrm{m}$ long, 30-37 $\mu \mathrm{m}$ wide) showed a very distinctive outline (Figs 47-50). The cell body was globular with the hyposome slightly longer than the episome. From the apex emerged a thick round protuberance, slightly curved towards the left side. The antapex, displaced towards the right hyposome, tapered to a slender pointed extension (Figs 47-50).

\section{Colonial gymnodinioid dinoflagellates}

The colony-forming unarmoured dinoflagellates are scarce in the open ocean. A few records corresponded to 2-cell chains of specimens that may temporally remain attached after the cell division (Fig. 42). Other specimens corresponded to truly colonial forms (Figs 51-52). Figure 51 shows a chain of 4 cells with elongated hexagonal cell bodies. The cell size was $28 \mu \mathrm{m}$ in length and $16 \mu \mathrm{m}$ in width. The wide apex of each cell was attached to the antapex of the neighbour cell. The specimens from the extremities differed from the other cells of the colony. The episome of the first cell was less elongated than in the other cells. The base of the hyposome was wide, whereas in the last cell of the colony it was rounder (Fig. 51). This reveals the intraspecific variability of the shape between the individuals of a single chain. Other 4-cell colony showed cells of ellipsoidal shape (60 $\mu \mathrm{m}$ long, 30 $\mu \mathrm{m}$ wide). The junction between the cells in some cases was restricted to a point (Fig. 52). A two-cell chain differed from the previous colonies because the cells were attached by their hyposomes. The cells were elongated with a pointed episome and a high cingular displacement. The apices of both cells were acute (Fig. 53). The shape of the hyposome was quadrangular in one cell and was rounder in the other cell. The cell size was $101 \mu \mathrm{m}$ in length and $28 \mu \mathrm{m}$ in width (Fig. 53).

\section{DISCUSSION}

As a general trend, the gymnodinioid dinoflagellates did not show body extensions in neritic waters. For example, thecate dinoflagellates of the order Dinophysiales Lindemann, Dinophysis Ehrenberg that predominate in neritic waters are characterized by scarcely developed sulcal lists, whereas genera such as Ornithocercus Stein or Histioneis Stein have large sulcal 


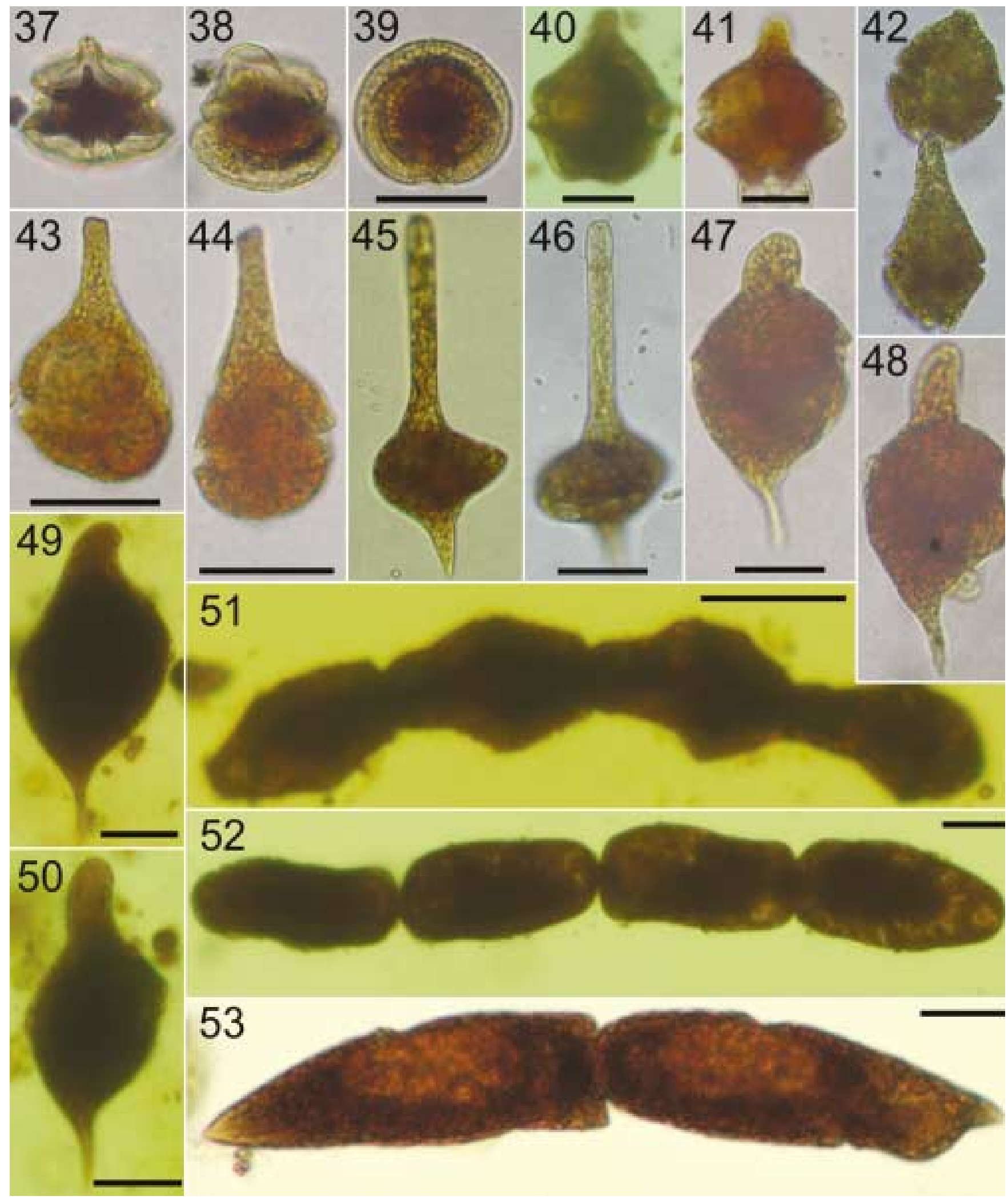

Figs 37-53. Photomicrographs of gymnodinioid cells, bright-field optics. See table 1 for the localization of the records. Figs 37-39. A specimen of Ptychodiscus noctiluca in different views. Fig. 40. Tentatively Berghiella sp. Fig. 41. Unidentified gymnodinioid dinoflagellate. Fig. 42. A two-cell chain with variable elongation of the episome. Figs 43-44. Two specimens with an apical extension of different length. Figs 45-46. Specimen with a long straight truncated apical horn and a short antapical extension. Figs 4750. Cells with a rounded apical protuberance and a pointed antapical extension. Fig. 51. Four-cell chain with elongated hexagonal cell body. Fig. 52. Four cell-chain with ellipsoidal cell body. Fig. 53. Two cells attached by the hyposome. Scale bars: $20 \mu \mathrm{m}$. 
lists predominate in the warm open ocean. Zirbel et al. (2000) demonstrated that turbulence inhibits the projection of body extensions in armoured dinoflagellates. The highly turbulent conditions that characterize coastal waters may inhibit the projection of body extensions when compared with the low turbulence conditions that predominate in the warm open ocean.

One of the essential contributions in the knowledge of unarmoured dinoflagellates is the monograph by Kofoid and Swezy (1921) that compiled the previous studies and described numerous new species from a single or a few specimens collected in the Californian coast. Most of these new species were never reported further. The observations of live specimens by these authors allowed detailed illustrations when compared with the previous descriptions. Kofoid and Swezy collected their specimens using techniques based on net sampling, with the consequent underestimation of the small forms and the damage of the delicate body extensions. Although they tried to reduce the time between the specimen capture and observation at the laboratory, the period is long enough to allow the specimens to modify theirs shapes. This may explain the high percentage of new species described by Kofoid and Swezy covered by a hyaline cyst, rounder cell bodies and the retraction of the body extensions in response to the stress of the sample treatment. During the next decades most of the studies were based on formalin-preserved net samples and there was little progress in the knowledge of the oceanic gymnodinioid dinoflagellates with body extensions. For example very distinctive genera with body extensions such as Brachidinium, Asterodinium, Microceratium and Pseliodinium were not described until the 1960-70s.

\section{Gyrodinium falcatum}

Gymnodinium fusus Schütt was one the first described and more common dinoflagellates with processes or body extensions. It was described from preserved samples collected in an indeterminate position in the North Atlantic or the Mediterranean at Naples (Schütt 1895). Kofoid and Swezy (1921) described the genus Gyrodinium for gymnodinioid cells with the cingulum displaced more than 0.2 of the total length of the body. The original description of G. fusus included a spindleshaped specimen and other individuals with short apical and antapical extensions and a higher cingular displacement (Schütt 1895). Kofoid and Swezy (1921) considered the illustration of this last individual as a separate species and they proposed Gyrodinium falcatum based on a modified illustration of one of the three figures provided by Schütt. Sournia (1972) described the Pseliodinium vaubanii based on Lugol-preserved bottle samples from surface tropical waters. The description by Sournia was focused on the extensions, with scarce detail on the cingulum, sulcus and it also reported a doubtful secondary nucleus (Sournia 1986), there are no further reports. Elbrächter (1979) observed live specimens of G. falcatum and reported the changes of shape and the formation of hyaline cysts in response to the capture and manipulation. He observed that after half hour the same specimen change towards the spindle-like shape and the cingulum was more displaced. This explains how first records of $G$. falcatum in the literature corresponded to morphotypes with shorter extensions. Elbrächter (1979) considered G. falcatum as a synonym of $G$. fusus, and he used the name G. fusus as that had priority. From a culture, Yoshimatsu (1990) reported micrographs of individuals with variable degree of elongation of the extensions, including the spindle-shaped individuals. Konovalova (2003) investigated the life cycle of G. falcatum from coastal waters. She concluded that $P$. vaubanii was the last life stage of $G$. falcatum. Gyrodinium sugashimanii J. Cachon, H. Sato, M. Cachon $e t \mathrm{~S}$. Sato was described based on the characteristics of G. falcatum (Cachon et al. 1989). It is invalid taxa following the rules of the I.C.B.N. and in any case is simply a synonym of G. falcatum. Based on the observation of a single specimen, encapsulated in a hyaline cyst, Kofoid and Swezy (1921) described Gyrodinium caudatum (non Gymnodinium caudatum Prescot). This taxon was characterized by a broadly fusiform body with abruptly contracted apical and antapical extensions. The cingulum displacement, sulcus and the position of the nucleus were similar to those in G. falcatum. Kofoid and Swezy (1921) discussed the similarity with G. fusus. They based the species diagnosis on the size differences. Kofoid and Swezy reported a transdiameter of $33 \mu \mathrm{m}$ and $66 \mu \mathrm{m}$ for G. caudatum and G. fusus, respectively. The size is a poor taxonomical criterion for the diagnosis of unarmoured dinoflagellates, especially for species with considerable shape plasticity such as G. falcatum, and the precision of the earlier size measurements should be cautiously considered. Elbrächter (1979) reported that the transdiameter of G. falcatum ranged from 32-69 $\mu \mathrm{m}$. Gyrodinium caudatum was covered by a hyaline capsule as illustrated by Konovalova (2003) for G. falcatum. This seems to indicate that the single specimen of G. caudatum observed by Kofoid and Swezy corresponded to a stressed specimen of G. falcatum. All these features suggest that the species 
Table 1. Geographic coordinates (latitude, longitude), depth (m), date of the records of gymnodinioid cells illustrated in the figures 253

\begin{tabular}{|c|c|c|c|c|c|}
\hline Taxon & Depth & Latitude & Longitude & Date & Figures \\
\hline Gyrodinium falcatum (spindle-shaped) & 150 & $0^{\circ}$ & $175^{\circ} \mathrm{W}$ & $22 / 01 / 2003$ & 2 \\
\hline G. falcatum (thick extensions) & 0 & $0^{\circ}$ & $175^{\circ} \mathrm{W}$ & $22 / 01 / 2003$ & 3 \\
\hline G. falcatum (thin extensions) & 15 & $0^{\circ}$ & $180^{\circ}$ & $21 / 01 / 2003$ & 4 \\
\hline G. falcatum (different extensions) & 30 & $32^{\circ} 42^{\prime} \mathrm{S}$ & $84^{\circ} 04^{\prime} \mathrm{W}$ & $02 / 12 / 2004$ & 5 \\
\hline G. falcatum (thin extensions) & 0 & $0^{\circ}$ & $175^{\circ} \mathrm{W}$ & $22 / 01 / 2003$ & 6 \\
\hline Gyrodinium falcatum (spindle-shaped) & 120 & $0^{\circ}$ & $165^{\circ} \mathrm{E}$ & $15 / 01 / 2003$ & 7 \\
\hline G. falcatum (different extensions) & 15 & $0^{\circ}$ & $180^{\circ}$ & $21 / 01 / 2003$ & 8 \\
\hline G. falcatum (thin extensions) & 20 & $8^{\circ} 50^{\prime} \mathrm{N}$ & $121^{\circ} 48^{\prime} \mathrm{E}$ & $03 / 12 / 2002$ & 9 \\
\hline G. falcatum with elongated apex & 30 & $32^{\circ} 42^{\prime} \mathrm{S}$ & $84^{\circ} 04^{\prime} \mathrm{W}$ & $02 / 12 / 2004$ & 10 \\
\hline G. falcatum with elongated apex & 45 & $23^{\circ} 32^{\prime} \mathrm{S}$ & $117^{\circ} 52^{\prime} \mathrm{W}$ & $10 / 11 / 2004$ & 11 \\
\hline G. falcatum with elongated apex & 35 & $20^{\circ} 27^{\prime} \mathrm{S}$ & $122^{\circ} 53^{\prime} \mathrm{W}$ & $08 / 11 / 2004$ & 12 \\
\hline Tentative Gyrodinium caudatum & 20 & $5^{\circ} 13^{\prime} \mathrm{N}$ & $120^{\circ} 46^{\prime} \mathrm{E}$ & $18 / 11 / 2002$ & 13 \\
\hline G. caudatum (single short extension) & 40 & $0^{\circ}$ & $170^{\circ} \mathrm{W}$ & $23 / 01 / 2003$ & 14 \\
\hline G. caudatum (long short extension) & 30 & $0^{\circ}$ & $165^{\circ} \mathrm{E}$ & $17 / 01 / 2003$ & 15 \\
\hline Pseliodinium vaubanii & 20 & $7^{\circ} 25^{\prime} \mathrm{N}$ & $121^{\circ} 12^{\prime} \mathrm{E}$ & $19 / 11 / 2002$ & 16 \\
\hline Pseliodinium vaubanii & 5 & $30^{\circ} 30^{\prime} \mathrm{N}$ & $138^{\circ} \mathrm{E}$ & $13 / 05 / 2002$ & 17 \\
\hline Pseliodinium vaubanii & 50 & $7^{\circ} 25^{\prime} \mathrm{N}$ & $121^{\circ} 12^{\prime} \mathrm{E}$ & $19 / 11 / 2002$ & 18 \\
\hline Pseliodinium vaubanii & 30 & $5^{\circ} 10^{\prime}$ & $124^{\circ} 04^{\prime} \mathrm{E}$ & $16 / 11 / 2002$ & 19 \\
\hline Pseliodinium vaubanii (curly extensions) & 100 & $32^{\circ} 30^{\prime}$ & $138^{\circ} \mathrm{E}$ & $07 / 07 / 2002$ & 20 \\
\hline Pseliodinium vaubanii (curly extensions) & 60 & $31^{\circ} \mathrm{N}$ & $138^{\circ} \mathrm{E}$ & $06 / 07 / 2002$ & 21 \\
\hline Pseliodinium vaubanii (curly extensions) & 20 & $34^{\circ} 39^{\prime} \mathrm{N}$ & $139^{\circ} 31^{\prime} \mathrm{E}$ & $07 / 06 / 2003$ & 22 \\
\hline Protoperidinium-like unarmoured cell & 120 & $0^{\circ}$ & $180^{\circ}$ & $21 / 01 / 2003$ & $23-24$ \\
\hline Protoperidinium-like unarmoured cell & 25 & $33^{\circ} 21^{\prime} \mathrm{S}$ & $78^{\circ} 06^{\prime} \mathrm{W}$ & $04 / 12 / 2004$ & $25-26$ \\
\hline Pacifier-shaped cell & 180 & $28^{\circ} 31^{\prime} \mathrm{S}$ & $104^{\circ} 18^{\prime} \mathrm{W}$ & $21 / 11 / 2004$ & $27-28$ \\
\hline Cell with elongated bifurcated hyposome & 20 & $34^{\circ} 39^{\prime} \mathrm{N}$ & $139^{\circ} 31^{\prime} \mathrm{E}$ & $07 / 06 / 2003$ & $29-30$ \\
\hline Cell with elongated bifurcated hyposome & 40 & $17^{\circ} 13^{\prime} \mathrm{S}$ & $127^{\circ} 58^{\prime} \mathrm{W}$ & $06 / 11 / 2004$ & 31 \\
\hline Very elongated cell with cingular lists & 100 & $8^{\circ} 23^{\prime} \mathrm{S}$ & $141^{\circ} 14^{\prime} \mathrm{W}$ & $26 / 10 / 2004$ & 32 \\
\hline Cell with semicircular episome & 0 & $0^{\circ}$ & $170^{\circ} \mathrm{E}$ & $18 / 01 / 2003$ & 33 \\
\hline Cell with biconical hyposome & 10 & $33^{\circ} 45^{\prime}$ & $138^{\circ} \mathrm{E}$ & $07 / 07 / 2002$ & 34 \\
\hline Cell with biconical hyposome & 10 & $30^{\circ}$ & $138^{\circ} \mathrm{E}$ & $04 / 07 / 2002$ & 35 \\
\hline Cell under division & 175 & $34^{\circ} 15^{\prime}$ & $138^{\circ} \mathrm{E}$ & $07 / 07 / 2002$ & 36 \\
\hline Ptychodiscus noctiluca & 40 & $34^{\circ} 15^{\prime}$ & $138^{\circ} \mathrm{E}$ & $07 / 07 / 2002$ & $37-39$ \\
\hline Tentatively Berghiella sp. & 15 & $9^{\circ} \mathrm{S}$ & $136^{\circ} 51^{\prime} \mathrm{W}$ & $01 / 11 / 2004$ & 40 \\
\hline Unidentified specimen close to Berghiella & 5 & $30^{\circ} 30^{\prime} \mathrm{N}$ & $138^{\circ} \mathrm{E}$ & $06 / 07 / 2002$ & 41 \\
\hline Two-cell chain with variable episome & 5 & $34^{\circ} 39^{\prime} \mathrm{N}$ & $139^{\circ} 31^{\prime} \mathrm{E}$ & $07 / 06 / 2003$ & 42 \\
\hline Cell with elongate apex & 30 & $30^{\circ} 30^{\prime} \mathrm{N}$ & $138^{\circ} \mathrm{E}$ & $06 / 07 / 2002$ & 43 \\
\hline Cell with elongate apex & 5 & $30^{\circ} 30^{\prime} \mathrm{N}$ & $138^{\circ} \mathrm{E}$ & $06 / 07 / 2002$ & 44 \\
\hline Cell with long straight apical extension & 20 & $6^{\circ} 54^{\prime} \mathrm{N}$ & $119^{\circ} 11^{\prime} \mathrm{E}$ & $22 / 11 / 2002$ & $45-46$ \\
\hline Cell with round apical protuberance & 40 & $34^{\circ} 15^{\prime} \mathrm{N}$ & $138^{\circ} \mathrm{E}$ & $07 / 07 / 2002$ & 47 \\
\hline Cell with round apical protuberance & 50 & $32^{\circ} 30^{\prime} \mathrm{N}$ & $138^{\circ} \mathrm{E}$ & $11 / 05 / 2002$ & 48 \\
\hline Cell with round apical protuberance & 5 & $31^{\circ} 52^{\prime} \mathrm{S}$ & $91^{\circ} 24^{\prime} \mathrm{W}$ & $27 / 11 / 2004$ & 49 \\
\hline Cell with round apical protuberance & 40 & $31^{\circ} 52^{\prime} \mathrm{S}$ & $91^{\circ} 24^{\prime} \mathrm{W}$ & $27 / 11 / 2004$ & 50 \\
\hline Four-cell chain with hexagonal shape & 180 & $28^{\circ} 31^{\prime} \mathrm{S}$ & $104^{\circ} 18^{\prime} \mathrm{W}$ & $21 / 11 / 2004$ & 51 \\
\hline Four-cell chain with ellipsoidal shape & 60 & $31^{\circ} 52^{\prime} \mathrm{S}$ & $91^{\circ} 24^{\prime} \mathrm{W}$ & $27 / 11 / 2004$ & 52 \\
\hline Two-cell chain with attached hyposome & 20 & $33^{\circ} 30^{\prime} \mathrm{N}$ & $138^{\circ} \mathrm{E}$ & $07 / 07 / 2002$ & 53 \\
\hline
\end{tabular}

Gymnodinium fusus, Gyrodinium falcatum, G. sugashimanii, G. caudatum and Pseliodinium vaubanii correspond to morphotypes of a single species with considerable shape plasticity. However, it is uncertain whether this taxon belongs to the genera Gymnodinium, Gyrodinium or dif- fers from those genera and Pseliodinium should be considered as the correct genus name.

For decades, it has been speculated that a cingular displacement of about $20 \%$ is not useful as a separating character between Gymnodinium and Gyrodinium. 
Additionally, culture studies have shown that considerable variation of this feature may occur, even within clones (Kimball and Wood 1965). Daugbjerg et al. (2000) and Hansen and Daugbjerg (2004) combined ultrastructural features and partial LSU rDNA sequences of the type species of Gymnodinium and Gyrodinium to redefine these genera. Beyond several ultrastructural characteristics, the shape of the apical groove was horseshoeshaped in anti-clockwise direction for the type species of Gymnodinium and elliptical bisected by a ridge for the type species of Gyrodinium. Takayama (1998, plate 9, fig. 6) reported a scanning electron microscopy picture of the apical groove of G. falcatum. The apical groove encircled the apex and a surface ridge dissects the apical groove and continues to the apex of the cell (Takayama 1998). The apical groove of G. falcatum seems to be closer to Gyrodinium than Gymnodinium. However, the type of Gyrodinium is a heterotrophic species and has surface striations when compared with G. falcatum. The shape of the apical groove is not the only morphological characteristic for generic diagnosis. For example the brachidiniaceans, including Karenia G. Hansen et Moestrup, and Karlodinium J. Larsen have straight apical grooves. Until further studies on the ultrastructure can clarify the systematic position of this taxon, four main options appear:

1) This taxon belongs to the genus Gyrodinium and the correct name is Gyrodinium falcatum. The transfer of Gymnodinium fusus to "Gyrodinium fusus" is not possible because the species name is occupied by Gyrodinium fusus (Meunier) Akselman;

2) This taxon belongs to the genus Gymnodinium and the correct species name is the basionym Gymnodinium fusus. If the synonymy between G. fusus and G. falcatum is not accepted, the later species may be transferred to the genus Gymnodinium as "Gymnodinium falcatum". To the best of my knowledge this new combination has never formally been proposed. However, de Salas et al. (2003) used the LSU rDNA sequence of a taxon named "Gymnodinium falcatum" in a phylogenetic tree. This taxon appeared in a separate lineage from several Gymnodinium species, including the type, and other unarmoured dinoflagellates (de Salas et al. 2003). In that phylogenetical tree species of Gyrodinium were absent, the first sequences appeared later in Hansen and Daugbjerg (2004). The recent comparison of the LSU rDNA sequence reported for "Gymnodinium falcatum" by de Salas et al. (2003) with other nucleotide sequences using the BLAST (Basic Alignment Search Tool) available at http://www.ncbi.nln.nih.gov/BLAST/ revealed that this "Gymnodinium falcatum" was closer to the genus Takayama de Salas, Bolch, Botes et Hallegraeff (de Salas et al. 2003). The genus Takayama is characterized by sigmoid apical grooves and it contains species ascribed previously to the genus Gymnodinium and Gyrodinium. De Salas et al. (2003) did not report any other information or micrographs of "Gymnodinium falcatum" in order to verify the identity of this taxon;

3) The shape of the apical groove is not the unique character for the generic separation. Other ultrastructural characters (nuclear envelope, flagellar root, surface striations, pigments, etc) were used for the separation between Gymnodinium and Gyrodinium or the recent genera recently erected from the split of Gymnodinium sensu lato (Daugbjerg et al. 2000). Despite the availability of cultures, these ultrastructural characters have not yet been reported for G. falcatum. It cannot be discarded that G. falcatum will belong to a different genus and consequently the first name available is Pseliodinium;

4) Gyrodinium falcatum is apparently a cosmopolitan species that may reach high abundances in coastal waters (Yoshimatsu 1990). However, it is impossible to discard the fact that that several different species, even of different genera, may converge to the shape of G. falcatum, and certainly we are dealing with different taxa, in different regions of the world oceans.

Until further research clarifies the generic status, in the present study Gyrodinium falcatum is used following the most usual species name in the literature. The present study has illustrated the diverse morphology of this interesting taxon in the open ocean. Gyrodinium falcatum, is easily cultivable and accessible in coastal waters, is a good taxon to investigate the mechanism of the projection of body extensions in gymnodinioid dinoflagellates.

\section{Gymnodinioid cells with bilobed hyposome}

For armoured dinoflagellates (Ceratium spp., Protoperidinium spp.) it is common to have two body extensions or horns projecting from the hyposome. The gymnodinioid species with two antapical extensions are rare, except for the brachidiniaceans that show a high diversity in the number and disposition of the extensions (Gómez 2006). Even rarer are gymnodinioid cells with two extensions from the episome. One of these taxa with a distinctive $\mathrm{H}$-shaped outline has been recently reported (Gómez 2007b). Some of the unarmoured dinoflagellates with bilobed hyposome resemble armoured dinoflagellates devoid of the theca (Figs 23-26). Numerous dinoflagellates in shallow coastal waters, including red tide 
species, form cysts that later germinate under favourable conditions (Bravo and Anderson 1994). Obviously in the open ocean the formation of cysts implies the sinking to the deep ocean with a low probability of returning to the euphotic zone. However, the excystment is not present in the case of the specimens illustrated in the present study (Figs 23-26). Some dinoflagellates have the ability to shed their theca when under stress and emerge as a nonmotile cell surrounded by a membrane and a thin, continuous wall. Consequently these cells after the ecdysis may be mistaken for truly unarmoured dinoflagellates. The outline of the specimen of the figures 25-26 is reminiscent of thecate dinoflagellates such as Protoperidinium elegans (Cleve) Balech. The length of the specimen of the figures 25-26 was $68 \mu \mathrm{m}$, whereas for P. elegans it was 150-220 $\mu \mathrm{m}$. Kofoid and Swezy (1921) described the species Gymnodinium bifurcatum Kofoid et Swezy and discussed the resemblance to a thecate dinoflagellate devoid of the theca. The episome of G. bifurcatum was semicircular in lateral view, whereas the two specimens of the present study showed horns (Figs 23-26). The distinction between an armoured dinoflagellate devoid of the theca or one of the unknown oceanic unarmoured dinoflagellates is not immediate. The ecdysis phenomenon in the open ocean needs to be investigated.

One of the morphological features observed in the present study in several oceanic gymnodinioid dinoflagellates was the presence of two concentric rings that encircle the cingulum (Figs 29-32). The cingular lists are known in some thecate dinoflagellates, but rarely in unarmoured dinoflagellates. Balech (1976) illustrated the cingular lists in Gymnodinium cf. diploconus Schütt. Gynogonadinium aequatoriale F. Gómez, a gymnodinioid dinoflagellate recently described from the open equatorial Pacific, showed cingular lists revealed by scanning electron microscopy (Gómez 2007a). The presence of cingular lists seems to be more common for the oceanic gymnodinioid dinoflagellates when compared with the coastal species.

\section{Unarmoured dinoflagellate with thick cell covers}

Although since Schütt (1895) the dinoflagellates have been traditionally divided into unarmoured and thecate, further detailed transmission electron microscopy studies showed that the distinction was not clear-cut, being considered as unarmoured were the species in which amphiesma vesicles were empty or contained only granular material (Dodge and Crawford 1970). Dinoflagellates with a strongly developed organic pelli- cle, assumed as the dominant amphiesmal element, were placed in the order Ptychodiscales Fensome et al. (Fensome et al. 1993). This order includes the marine genera Ptychodiscus Stein, Balechina Loeblich Jr. et Loeblich III, Berghiella, Ceratoperidinium Margalef, Sclerodinium Dodge, Amphilothus Schütt, Achradina Lohmann and the brachidiniaceans (Asterodinium, Brachidinium and Microceratium). These genera, all of them insufficiently known, poorly described and rarely reported in the literature, were grouped in the Ptychodiscales based on a supposed thick cell cover, although not apparently divided into component plates. However, the cell cover hasn't been investigated in detail in any of these genera. For example, the brachidiniaceans are far to have rigid cell covers because they are gymnodiniceans with body extensions, currently known as Karenia in coastal waters (Gómez et al. 2005). Steidinger (1979) transferred the species currently known as Karenia brevis (Davis) G. Hansen et Moestrup to Ptychodiscus because of the prominent apical carina and a resistant cell covering. The origin of the name Ceratoperidinium refereed to the resemblance with the outline of thecate dinoflagellates such as Ceratium Schrank and Heterodinium Kofoid. Despite the poor original description and lack of further records, this genus was placed in the order Peridiniales Haeckel. A first study on the morphology of Ceratoperidinium revealed the absence of thecal plates. The cell cover of Ceratoperidinium does not differ from that in other unarmoured dinoflagellates (Gómez et al. 2004).

Two other mysterious genera, Berghiella and Balechina, were grouped in the order Ptychodiscales. Kofoid and Michener (1911, p. 301), with no illustrations, defined the genus Berghiella as "form of a spheroidal Gonyaulax with a very abruptly differentiated low cylindrical apical horn with a truncated apex. Girdle with hyaline lists, descending, displaced less than a girdle width, not impressed. Ventral area not delimited posteriorly. Absolutely no trace of subdivision of theca into plates or regions. Type species B. perplexa". Kofoid and Swezy (1921) did not include the genus in the monograph of unarmoured dinoflagellates. Very little is known about the genus Berghiella and it is risky to consider that the rigid appearance of its outline can be used as a diagnostic character. No other authors have made further reports on the genus Berghiella with the exception of Taylor (1976). Taylor investigated the thecate dinoflagellates in the Indian Ocean from material collected by net sampling and were fixed with a high concentration of formalin. Despite the 
inappropriate method used for the delicate unarmoured dinoflagellates, this author observed several highly deformed large specimens of unarmoured dinoflagellates that survived the treatment. Despite the poor generic diagnosis of Berghiella, Taylor considered that one of the specimens that resisted the formalin-fixation belonged to this genus. Taylor (1976) described the new species Berghiella josephinae, although in this taxon the cingulum was not displaced and it was impressed when compared with the too brief description of the type species. To the best of my knowledge no other records of Berghiella exist. The present study illustrates a specimen that may correspond to the genus Berghiella (Fig. 40). The specimen showed a deep impressed and horizontal cingulum. These features differed from the original description of Berghiella by Kofoid and Michener (1911) and closer to Berghiella josephinae as illustrated by Taylor (1976). In that case, figure 40 may correspond to the first record of the genus Berghiella in the Pacific Ocean after the initial description and the first micrograph existing in the literature.

Kofoid and Swezy (1921) separated the genus Gymnodinium into several subgenera. The subgenus Balechina corresponded to species with a distinctly thickened pellicle. The genus Balechina, with B. pachydermata (Kofoid et Swezy) Loeblich Jr. et Loeblich III as type species, was created when members of the subgenus Pachydinium Kofoid et Swezy of the genus Gymnodinium were raised to the status of a genus and a genus Pachydinium Pavillard was already in existence (Loeblich and Loeblich III 1968). Despite the poor definition of the genus Balechina, Taylor assumed that one of the highly distorted of Gymnodinium coeruleum Dogiel should belong to the genus Balechina. Taylor (1976) based on a supposed rigid cell cover proposed the new combination Balechina coerulea (Dogiel) F.J.R. Taylor. There is not doubt on the validity of Gymnodinium coeruleum, a large mixotrophic species reported by other authors (Kimor 1981). However, it is questionable the generic transfer to a poor defined genus based on a single highly deformed specimen. The subgenus Pachydinium as defined by Kofoid and Swezy included species with the surface marked by striae or ridges, or smooth. Takayama (1998) investigated by scanning electron microscopy the type species of the genus, B. pachydermata, that showed a mammilate cell surface, while G. coeruleum showed numerous longitudinal grooves on the cell surface. This reveals that the transfer of species $G$. coeruleum to the genus Balechina is not justified due to the differences with the type species. The longitudinal grooves also reveal that $G$. coeruleum may not belong to the genus Gymnodinium which is characterized by a smooth cell surface. Further studies will determinate the correct generic status of G. coeruleum. Taylor (1976) also described the new species Balechina marianae with longitudinal grooves, that are lacking in the type species of Balechina.

The new generic name Sclerodinium was proposed for cells with tough or hard cell covering which contrast with the weak cover typical of Gyrodinium. The genus Sclerodinium was only used by its authority (Dodge 1981). The genus Amphitholus Schütt is only known from the poor original description in 1895 (Schütt 1895). In the order Ptychodiscales, the rigid appearance of the cell cover, with no detailed studies by electron microscopy, is a poor criterion for the species diagnosis. It depends on the cell cover properties, but may also vary according to the type of fixative and its concentration and the subjectivity of the observer. If the poor-defined genera such as Amphitholus, Balechina, Berghiella and Sclerodinium, and obviously the brachidiniaceans (Brachidinium, Asterodinium, Microceratium, Karenia), are excluded from the order Ptychodiscales only the monotypic genus Ptychodiscus remains. Ptychodiscus noctiluca is accessible even in coastal warm waters and as such is a good candidate to investigate the nature of the dinoflagellate cell covers. The order Ptychodiscales, an unfortunate compilation of insufficiently known dinoflagellates belonging to other groups, cannot be based on the characteristics of a single species that has not been investigated in detail.

\section{Other dinoflagellates with body extensions}

The gymnodinioid dinoflagellates with a single apical extension as illustrated in the present study (Figs 43-44), are rarely reported in the literature and to the best of my knowledge no species with a single apical extension has been described. It should be taken into account that the apical extension is a poor characteristic for the species diagnosis due to its intraspecific variability (Fig. 42). The most typical apical extension is a straight truncated horn. The present study shows specimens with other types of extension as a curved rounded protuberance (Figs 47-50). The appearance of these distinctive cells should not be mistaken for cells deformed due the ingestion of large prey items as usual in Gyrodinium spirale (Bergh) Kofoid et Swezy. The specimens of the figures 47-50 were found in geographically distant areas from the temperate North and South Pacific, suggesting that they correspond to a 
new species that required more detailed studies to be formally described (Figs 47-50).

\section{Colonial gymnodinioid dinoflagellates}

The formation of colonies is a common feature in other groups of non-motile phytoplankton such as the diatoms. The colonial forms, of both unarmoured and armoured dinoflagellates, are scarcely represented in the open ocean when compared with neritic waters. Colonial or pseudo-colonial species belonging to genera such as Alexandrium Halim, Gymnodinium Stein or Polykrikos Bütschli often proliferate in coastal waters. The colonial dinoflagellates offer an opportunity to observe the intraspecific morphological variability of the dinoflagellates, because it is assumed that all the specimens of the colony belong to the same species. The present study illustrates specimens of the same colony that showed differences in cell elongation (Fig. 51). The cells at the extremes were less elongated, especially in the region of junction of the hyposome or episome that varies between attached and unattached cells.

The chain-forming strategy for red tide dinoflagellate species in coastal waters might represent an advantage in comparison with unicellular dinoflagellates. Fraga et al. (1989) reported that long chains increase the swimming speed of Gymnodinium catenatum Graham. This could facilitate escape from predators and the exploitation of nutrients in subphotic depths during the night and photosynthesis during the day in the upper waters. In the open ocean, the nutricline is often located below $150 \mathrm{~m}$ depth, and this constitutes a long distance for a single day vertical migration. This may explain the very scarce presence of colonial autotrophic dinoflagellates in the open ocean, where also the general oligotrophic nature of the environment may not favor the grouped specimens.

It is more common in colonial species that the episome of one cell is attached to the hyposome of the neighbour cell (Figs 51-52). Figure 53 shows a cell pair attached by their hyposome. This can also be observed in armoured dinoflagellates (i.e., Protoperidinium denticulatum (Gran et Braarud) Balech) and in the freshwater species Gymnodinium uberrimum (Allman) Kofoid et Swezy. It is uncertain whether this orientation between the cells may affect the chain swimming behaviour and locomotion efficiency when compared with the usual colonial dinoflagellates. This phenomenon of cell pairs attached by their hyposome may be related to the sexual reproduction or other temporal phenomenon. However, cell pairs of Protoperidinium denticulatum are a permanent feature and consequently this cannot be discarded in pairs of gymnodinioid cells.

The present study has illustrated numerous gymnodinioid dinoflagellates from the open ocean, rarely reported in the literature due to the scarcity of studies in the open ocean, especially in warm waters. The examples illustrated herein reveal the considerable unknown diversity of gymnodinioid dinoflagellates in world oceans.

\section{ACKNOWLEDGEMENTS}

Studies from NW and Equatorial Pacific Ocean were supported by a Grant-in-aid for Creative Basic Research (12NP0201, DOBIS) from the MEXT, Japan, and in the SE Pacific Ocean within the context of the project BIOSOPE of the LEFE-CYBER. I was supported by a fellowship of the European Commission (ICB2-CT-2001-80002) held at the University of Tokyo with Prof. K. Furuya as host. I thank Y. Fukuyo and Y. Nagahama for the support and A. Pollard for the English edition. I thank the support of a post-doctoral grant by Ministerio Español de Educación y Ciencia 2007-0213.

\section{REFERENCES}

Balech E. 1976. Clave ilustrada de dinoflagelados antárticos. Instituto Antártico Argentino, Publicación 11, Buenos Aires.

Bravo I. and Anderson D.M. 1994. The effects of temperature, growth medium and darkness on excystment and growth of the toxic dinoflagellate Gymnodinium catenatum from northwest Spain. J. Plankton Res. 16: 513-525.

Cachon J., Sato H., Cachon M. and Sato S. 1989. Analysis by polarizing microscopy of chromosomal structure among dinoflagellates and its phylogenetic involvement. Biol. Cell. 65: 51-60.

Daugbjerg N., Hansen G., Larsen J. and Moestrup Ø. 2000. Phylogeny of some of the major genera of dinoflagellates based on ultrastructure and partial LSU rDNA sequence data, including the erection of three new genera of unarmoured dinoflagellates. Phycologia 39: 302-317.

Dodge J.D. 1981. Three new generic names in the Dinophyceae: Herdmania, Sclerodinium, and Triadinium to replace Heteraulacus and Goniodoma. Br. Phycol. J. 16: 273-280.

Dodge J.D. and Crawford R.M. 1970. A survey of thecal fine structure in the Dinophyceae. Bot. J. Linn. Soc. 64: 105-115.

Elbrächter M. 1979. On the taxonomy of unarmored dinophytes (Dinophyta) from the Northwest African upwelling region. 'Meteor' Forschungs. Reihe D 30: 1-22.

Fensome R.A., Taylor F.J.R., Norris G., Sarjeant W.A.S., 
Wharton D.I. and Williams G.L. 1993. A classification of living and fossil dinoflagellates. American Museum of Natural History, Sheridan Press, Hanover, Pennsylvania.

Fraga S., Gallager S.M. and Anderson D.M. 1989. Chain-forming dinoflagellates: An adaptation to red tides. In: Anderson D.M. and Nemoto T. (eds), Red Tides: Biology, Environmental Science and Toxicology. Proceedings of the First International Symposium on Red Tides, Takamatsu, Japan. pp. 281-284.

Gómez F. 2006. The dinoflagellate genera Brachidinium, Asterodinium, Microceratium and Karenia in the open SE Pacific Ocean. Algae 21: 445-452.

Gómez F. 2007a. Observations on an H-shaped dinoflagellate. An example of the projection of body extensions in gymnodiniacean cells. Acta Bot. Croat. 66: 75-79.

Gómez F. 2007b. Gynogonadinium aequatoriale gen. et sp. nov., a new dinoflagellate from the open western equatorial Pacific. Algae 22: 11-17.

Gómez F., Nagahama Y., Fukuyo Y. and Furuya K. 2004. Observations on Ceratoperidinium (Dinophyceae). Phycologia 43: 416-421.

Gómez F., Nagahama Y., Takayama H. and Furuya K. 2005. Is Karenia a synonym of Asterodinium-Brachidinium? (Gymnodiniales, Dinophyceae). Acta Bot. Croat. 64: 263-274.

Hansen G. and Daugbjerg N. 2004. Ultrastructure of Gyrodinium spirale, the type species of Gyrodinium (Dinophyceae), including a phylogeny of G. dominans, G. rubrum and G. spirale deduced from partial LSU rDNA sequences. Protist 155: 271-294.

Kimball J.F. and Wood E.J.F. 1965. A dinoflagellate with characters of Gymnodinium and Gyrodinium. J. Protozool. 13: 577580 .

Kimor B. 1981. Seasonal and bathymetric distribution of thecate and non-thecate dinoflagellates off La Jolla, California. CalCOFI Rep. 22: 126-134.

Kofoid C.A. and Michener J.R. 1911. New genera and species of dinoflagellates. Museum of Comparative Zoology at Harvard
College, Bulletin 54: 1-265.

Kofoid C.A. and Swezy O. 1921. The free-living unarmoured Dinoflagellata. University of California Press, Berkeley.

Loeblich A.R. Jr. and Loeblich A.R. III. 1968. Index to the genera, subgenera and sections of the Pyrrhophyta, II. J. Paleont. 42: 210-213.

de Salas M.F., Bolch C.J.S., Botes L., Nash G., Wright S.W. and Hallegraeff G.M. 2003. Takayama gen. nov. (Gymnodiniales, Dinophyceae), a new genus of unarmoured dinoflagellates with sigmoid apical grooves, including the description of two new species. J. Phycol. 39: 1233-1246.

Schütt F. 1895. Peridineen der Plankton-Expedition. Ergebn. Plankton-Expedition der Humboldt-Stiftung 4: 1-170.

Sournia A. 1986. Atlas du Phytoplancton Marin. Vol. I: Introduction, Cyanophycées, Dictyochophycées, Dinophycées et Raphidophycées. Editions CNRS, Paris.

Steidinger K.A. 1979. Collection, enumeration and identification of free-living marine dinoflagellates. In: Taylor D.L. and Seliger H.H. (eds), Toxic Dinoflagellate Blooms. ElsevierNorth Holland, New York. pp. 435-442.

Takayama H. 1998. Morphological and taxonomical studies of the free-living unarmored dinoflagellates occurring in the Seto Inland Sea and adjacent waters. PhD. The University of Tokyo (in Japanese).

Taylor F.J.R. 1976. Dinoflagellates from the International Indian Ocean Expedition. A report on material collected by R/V "Anton Bruun" 1963-1964. Bibliotheca Bot. 132: 1-234.

Yoshimatsu S. 1990. Gyrodinium falcatum Kofoid et Swezy. In: Fukuyo et al. (eds), Red tide organisms in Japan. An illustrated taxonomic guide. Uchida Rokakuho, Tokyo. pp. 60-61.

Zirbel M.J., Veron N.F. and Latz M.I. 2000. The reversible effect of flow on the morphology of Ceratocorys horrida (Peridiniales, Dinophyta). J. Phycol. 36: 46-58.

Received 23 June 2007

Accepted 10 October 2007 